\section{Mouse-ear of Pecan: A Nickel Deficiency}

\author{
Bruce W. Wood, ${ }^{1}$ Charles C. Reilly, and Andrew P. Nyczepir \\ United States Department of Agriculture, Agricultural Research Service, \\ Southeastern Fruit and Tree Nut Research Laboratory, Byron, GA 31008-0087
}

Additional index words. nutrient disorder, zinc toxicity, flowering, profit, yields, stress, growth, micronutrients

\begin{abstract}
Mouse-ear (ME) is a potentially severe anomalous growth disorder affecting pecan [Carya illinoinensis (Wangenh.) K. Koch] trees. It is especially severe in second generation sites throughout much of the Gulf Coast Coastal Plain of the southeastern U.S., but can also occur in potted nursery trees. Orchard and greenhouse studies on trees treated with either $\mathrm{Cu}$ or $\mathrm{Ni}$ indicated that foliar applied Ni corrects ME. ME symptoms were prevented, in both orchard and greenhouse trees, by a single mid-October foliar spray of $\mathrm{Ni}$ (nickel sulfate), whereas nontreated control trees exhibited severe ME. Similarly, post budbreak spring spray applications of $\mathrm{Ni}$ to foliage of shoots of orchard trees exhibiting severe ME prevented ME symptoms on subsequent growth, but did not correct morphological distortions of foliage developed before Ni treatment. Foliar application of $\mathrm{Cu}$ in mid-October to greenhouse seedling trees increased ME severity the following spring. Post budbreak application of $\mathrm{Ni}$ to these $\mathrm{Cu}$ treated MEed seedling trees prevented $\mathrm{ME}$ symptoms in post Ni application growth, but did not alter morphology of foliage exhibiting ME before Ni treatment. Thus, high leaf $\mathrm{Cu}$ concentrations appear to be capable of disrupting Ni dependent physiological processes. Foliar application of Ni to ME prone trees in mid-October or soon after budbreak, is an effective means of preventing or minimizing ME. These studies indicate that $\mathrm{ME}$ in pecan is due to a Ni deficiency at budbreak. It also supports the role of $\mathrm{Ni}$ as an essential plant nutrient element.
\end{abstract}

A Mouse-ear (ME) is a growth abnormality of pecan [Carya illinoinensis (Wangenh.) K. Koch] first reported in 1918 by Marz (1918). It was initially exhibited by yard trees within certain Florida, southern Mississippi, and southeastern Georgia cities (Demaree, 1926). The disorder was initially attributed to spring cold injury before budbreak, but was later attributed to a disease pathogen (Demaree, 1926). It was evident in pecan orchards by the 1930's and is now a common anomaly. Gammon and Sharpe (1956) concluded that the problem was a manganese deficiency; however, soil or foliar application of Mn to affected trees does not correct ME in contemporary orchards. Mouseear symptoms range from mild morphological distortion of leaflets to gross deformity of shoot, foliar, and reproductive organs (Wood et al., 2003a).

There has been considerable establishment of second generation pecan orchards and replacement of missing orchard trees over the last 20 years in the southeastern U.S. It is common for these newly transplanted trees to exhibit ME symptoms the second or third year after transplanting. In many cases symptoms are so severe that transplants die. This replant-associated form of ME is a serious economic problem for many orchard operations throughout the Georgia pecan belt and certain orchards within the Gulf Coast Coastal Plain of the southeastern U.S.

Mouse-ear symptomology, as recently

Received for publication 22 Aug. 2003. Accepted for publication 8 Mar. 2004

${ }^{1}$ Corresponding author; e-mail bwwood@saa.ars. usda.gov. described by Wood et al. (2003a), implicates a micro nutrient deficiency or imbalance as the causal factor. This conclusion was further supported by observations by Wood et al. (2003b) that soil applied $\mathrm{Cu}$ at time of transplanting corrected ME on a second generation site. Trees exhibiting mild to moderate ME growing on a first generation site were largely cured of $\mathrm{ME}$ by the third year after topical application of $\mathrm{Cu}$ to the soil; however, foliar applications of $\mathrm{Cu}$ generally had little or no influence on $\mathrm{ME}$ severity. Neither foliar or soil application of $\mathrm{Cu}$ to severely MEed trees were efficacious for reducing symptoms. It was also noted that on a first generation orchard site, soil application of high amounts of either $\mathrm{P}$ or $\mathrm{S}$ corrected ME symptoms three years after application. Wood et al. (2004a) also noted a strong statistical linkage between $\mathrm{Cu}$ and $\mathrm{Zn}$ in regards to ME severity, thus implicating a $\mathrm{Zn}$ induced temporary deficiency of $\mathrm{Cu}$ as the likely cause of ME. However, these findings did not exclude deficiencies of other divalent metallic cations (e.g., $\mathrm{Ni}, \mathrm{Co}, \mathrm{Ti}$, or $\mathrm{V}$ ) as being the cause of ME.

Wood et al. (2004a, 2004b) observed a strong relationship between ME severity and soil $\mathrm{Zn}$ content, thus implicating $\mathrm{Zn}$ as a contributing factor to $\mathrm{ME}$. Because $\mathrm{Zn}, \mathrm{Cu}$ and $\mathrm{Ni}$ ion uptake from soils by feeder roots appear to share the same ion channels for entry into the root vascular system (Kochian, 1991), it becomes apparent that ME might be caused by either a $\mathrm{Ni}$ or $\mathrm{Cu}$ deficiency that is being induced by excessive soil $\mathrm{Zn}$ on second generations sites and by low soil $\mathrm{Ni}$ or $\mathrm{Cu}$ on first generation sites. The present study evaluates whether severe ME can be corrected by foliar applications of either $\mathrm{Ni}$ or $\mathrm{Cu}$ and concludes that ME is caused by Ni deficiency.

\section{Materials and Methods}

Field studies. Severely affected ME trees were treated in commercial orchards throughout the Gulf Coast Coastal Plain of Georgia. Soil types among affected orchards differed substantially, but were almost always either sandy loams or sands. Affected trees were found on sites previously supporting pecan orchards or were replacement trees in existing mature orchards. Although, ME affected trees sometime occurred on sites where pecan had not previously grown. In the latter case, these soils possessed very low cation exchange capacities. Most of the affected cultivars were 'Desirable' and were from 5 to 10 years old. The rootstocks are unknown, but are likely seedlings of 'Elliott', a commonly used seed source for pecan rootstock in the southeastern U.S.

Fall application. The ability of fall foliar application of either $\mathrm{Cu}$ or $\mathrm{Ni}$ to correct ME was evaluated in several orchards. The experiment consists of three micro nutrient treatments (Control, $\mathrm{Cu}$ and $\mathrm{Ni}$ ) applied 15 Oct. as a foliar spray to major branches of severely MEed 'Desirable' trees. Individual trees served as replicates comprised of all three micro nutrient treatments. Treatments were spatially separated within the tree canopy so as to avoid cross-contamination of sprays. All treatments contained reagent grade urea (at 4.8 $\left.\mathrm{g} \cdot \mathrm{L}^{-1}\right)$ and a nonionic surfactant $\left(2.5 \mathrm{~mL} \cdot \mathrm{L}^{-1}\right)$ as additives. The $\mathrm{Cu}$ source was $\mathrm{CuSO}_{4} \cdot 5 \mathrm{H}_{2} \mathrm{O}$ at a concentration of $4 \mathrm{~g} \cdot \mathrm{L}^{-1}\left(1 \mathrm{~g} \cdot \mathrm{L}^{-1} \mathrm{Cu}\right)$. The $\mathrm{Ni}$ source was $\mathrm{NiSO}_{4} \bullet 6 \mathrm{H}_{2} \mathrm{O}$ at a concentration of $3.5 \mathrm{~g} \cdot \mathrm{L}^{-1}\left(0.8 \mathrm{~g} \cdot \mathrm{L}^{-1} \mathrm{Ni}\right)$. Both salts used in this experiment, and in the following experiments, were $99 \%$ A.C.S. reagent grade (Aldrich, Milwaukee, Wisconsin). Control treatments received only reagent grade urea and surfactant. Sprays were applied to foliage till run-off. There were 20 replications dispersed over two orchard sites. The experiment was a $\mathrm{RCB}$ design comprised of three treatments with single tree blocks. Treatments were evaluated the following spring (1 May) for severity of ME. Severity was based on the following scale; $1=$ no symptoms, 2 = between $1 \%$ and $25 \%$ of number of leaflets per shoot exhibiting blunting; $3=26 \%$ to $50 \%$ of number of leaflets per shoot exhibiting blunting; $4=>50 \%$ of number of leaflets per shoot exhibiting blunting; $5=$ cupping of blunted leaflets; $6=$ necrosis of leaflet tips; 7 = dark green zone near leaflet tip; $8=$ stunted shoots; $9=$ multiple new shoots (i.e., witches broom); $10=$ dead shoot. Data were statistically analyzed for mean separation of treatments by use of JMP (SAS, Cary, N.C; SAS Institute, 2002). Nickel content of foliage was determined by ICP spectroscopic analysis using standard techniques. Several leaves were collected per treatment in June, bulked, rinsed in $0.1 \mathrm{M} \mathrm{HCl}$, triple rinsed in deionized water, dried at $55 \mathrm{C}$, ground in a ceramic mortar and pestle before processing for analysis.

Spring application. This experiment addressed $\mathrm{Cu}$ or $\mathrm{Ni}$ applied to expanding shoots 
Table 1. Influence of fall and spring foliar applications of $\mathrm{Cu}$ or $\mathrm{Ni}$ on mouse-ear severity of pecan trees grown in orchards or potted seedlings in a greenhouse.

\begin{tabular}{|c|c|c|c|}
\hline \multicolumn{3}{|c|}{ Treatment } & \multirow{2}{*}{$\begin{array}{c}\text { Mouse-ear severity } \\
\text { (class) }^{\mathrm{w}}\end{array}$} \\
\hline Chemical $^{\mathrm{z}}$ & Application time ${ }^{y}$ & Tree type $^{x}$ & \\
\hline Control & Fall-15 Oct. & Orchard transplant & $7.4 \mathrm{a}^{\mathrm{v}}$ \\
\hline $\mathrm{Cu}$ & Fall-15 Oct. & Orchard transplant & $7.6 \mathrm{a}$ \\
\hline $\mathrm{Ni}$ & Fall-15 Oct. & Orchard transplant & $1.0 \mathrm{~b}$ \\
\hline Control & Early spring-1 Apr. & Orchard transplant & $7.7 \mathrm{~b}$ \\
\hline $\mathrm{Cu}$ & Early spring-1 Apr. & Orchard transplant & $8.1 \mathrm{a}$ \\
\hline $\mathrm{Ni}$ & Early spring-1 Apr. & Orchard transplant & $1.0 \mathrm{c}$ \\
\hline Control & Mid-spring-Ma ${ }^{\mathrm{u}}$ & Greenhouse seedling & $8.1 \mathrm{a}$ \\
\hline $\mathrm{Ni}$ & Mid-spring-Ma & Greenhouse seedling & $1.0 \mathrm{~b}$ \\
\hline
\end{tabular}

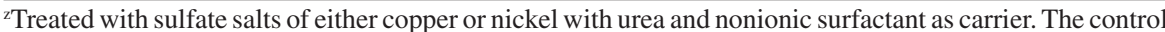
treatment received carriers but not the salts.

yTreatments were applied to foliage in either mid-October (fall) or early April about $10 \mathrm{~d}$ postbudbreak (spring)

xTreated trees were either orchard transplants or seedlings growing in a greenhouse.

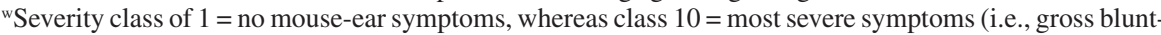
ing, curling, necrosis of leaflets; plus stunted shoots, multiple shoots, and death of shoots.

v Treatment means within each experiment are statistically different according to Tukey-Kramer HSD test $(a=0.05)$ if followed by different letters.

uTreatments applied early May after shoots were about one-half expanded, but youngest leaves and leaflets were in early stage of expansion.

soon after budbreak. The experimental design, treatments, and chemical sources were identical to the above fall application, except different trees were used. The expanding foliage and shoots were treated during the late parachute stage of leaf development in early April. All treatments contained reagent grade urea $\left(4.8 \mathrm{~g} \cdot \mathrm{L}^{-1}\right)$ and a nonionic surfactant $(2.5$ $\left.\mathrm{mL} \cdot \mathrm{L}^{-1}\right)$ as additives and applied till runoff. Treatments were assessed and analyzed as described above.

Greenhouse studies. The influence of $\mathrm{Cu}$ and $\mathrm{Ni}$ on ME of potted seedlings was evaluated by treating 1-year-old 'Desirable' pecan seedlings potted in soil from an orchard exhibiting severe ME. Seedling trees were germinated in May in vermiculite and transplanted in June to $15 \times 10 \mathrm{~cm}$ rectangular plastic pots containing

soil (95\% sand, $0 \%$ silt, $4 \%$ clay; $\mathrm{pH} 7.0$, o.m. $1.3 \%$ ) from a severely MEed orchard near Cordele, Ga. Seedlings were assessed and analyzed as described above.

Fall application. Trees were treated in October, just before leaf drop, with a single foliar spray of either $\mathrm{Cu}$ or $\mathrm{Ni}$. Copper and $\mathrm{Ni}$ were applied at one of five concentrations; i.e., $0,1 \times, 2 \times, 4 \times$, or $8 \times$; where for $\mathrm{Cu}, \mathrm{X}=1.98 \mathrm{~g}$ $\mathrm{CuSO}_{4} \cdot 5 \mathrm{H}_{2} \mathrm{O} / \mathrm{L}$; and for $\mathrm{Ni}, \mathrm{X}=3.53 \mathrm{~g} \mathrm{NiSO}_{4}$ - $6 \mathrm{H}_{2} \mathrm{O} / \mathrm{L}$. Spray application till run-off soaked the foliage while a barrier was used to prevent soil contamination. Trees were maintained until natural leaf drop in November by watering beneath the foliar canopy. Treated seedlings were left in unheated greenhouse during the dormant season. Trees broke bud about 15 Mar. and were subsequently rated for ME severity

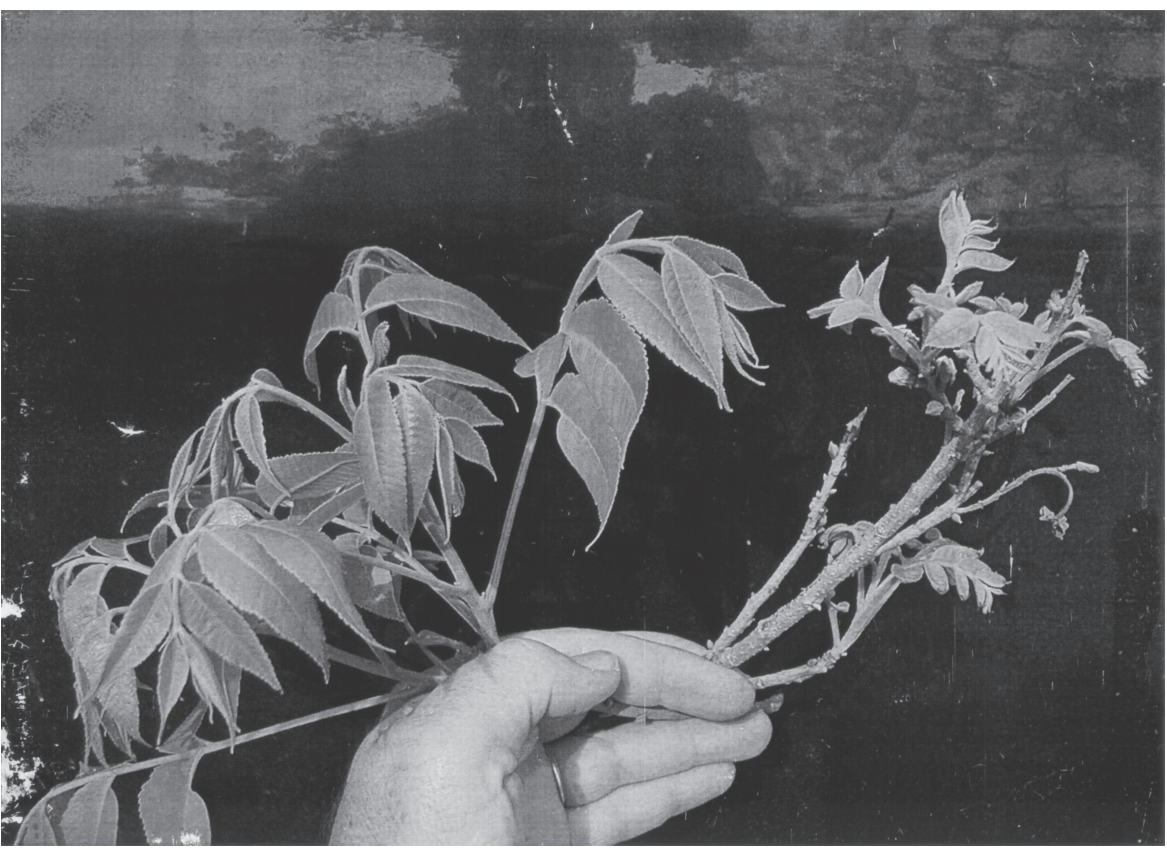

Fig. 1. Comparison of April 2003, shoot growth from severely mouse-eared trees treated with a folia spray of Ni the previous October and a nonsprayed control. The Ni treatment is on the left and the nontreated control is on the right. using the above described scale and data analyzed for treatment differences. The study was structured as two distinct experiments (one $\mathrm{Cu}$ and the other $\mathrm{Ni}$ ) in or with a RCB design with three blocks of five elemental concentrations $(0 \times, 1 \times, 2 \times, 4 \times$, and $8 \times)$ and eight trees per experimental unit. All treatments contained urea $\left(4.8 \mathrm{~g} \cdot \mathrm{L}^{-1}\right)$ and a nonionic surfactant $(2.5$ $\left.\mathrm{mL} \cdot \mathrm{L}^{-1}\right)$ as additives.

Spring application. A third Ni study was conducted using seedling trees of the abovementioned greenhouse $\mathrm{Cu}$ study. Because $\mathrm{Cu}$ treatments, regardless of the amount of Fall $\mathrm{Cu}$ applied to foliage, exhibited severe $\mathrm{ME}$ the following spring, affected trees were segregated and randomized and structured in a third experiment in which they were treated with a foliar spray of $\mathrm{Ni}\left(\mathrm{NiSO}_{4} \cdot 6 \mathrm{H}_{2} \mathrm{O}\right)$. Experimental design was a $\mathrm{RCB}$ comprised of three blocks (blocked by severity of ME) of two Ni treatments ( 0 vs. $3.53 \mathrm{~g} \cdot \mathrm{L}^{-1}$ as the sulfate salt) with 4 trees per experimental unit. Ni treatments were applied early May and the new shoot growth subsequently evaluated for ME severity. All treatments included urea (4.8 $\left.\mathrm{g} \cdot \mathrm{L}^{-1}\right)$ and a nonionic surfactant $\left(2.5 \mathrm{~mL} \cdot \mathrm{L}^{-1}\right)$ as additives. Data were then statistically analyzed for treatment differences.

\section{Results and Discussion}

\section{Field Studies}

Fall application. Limbs of trees receiving foliar sprays of $\mathrm{Ni}$ in October did not exhibit symptoms of ME the following spring whereas $\mathrm{Cu}$ treated and nontreated controls on the same tree exhibited severe ME (Table 1, Fig. 1). Shoots arising from $\mathrm{Ni}$ treated branches exhibited a ME rating of 1.0 (i.e., no symptoms of ME) whereas control trees exhibited a ME severity rating of 7.4 (i.e., severe ME) and the $\mathrm{Cu}$ treatment exhibited a severity rating of 7.6.

The October Ni treatment did not visually appear to be phytotoxic to either fall or spring foliage. These data indicate that the ME replant disorder of young pecan trees is tightly linked to a physiological deficiency of $\mathrm{Ni}$. This conclusion is supported by previous research reporting that $\mathrm{Ni}, \mathrm{Zn}$, and $\mathrm{Cu}$ are absorbed by the same carrier channel in roots and therefore competitively inhibit each others uptake from the soil solution (Kochian, 1991). Circumstantial evidence indicates that high soil $\mathrm{Zn}$, arising from many decades of foliar sprays to correct $\mathrm{Zn}$ deficiency, is likely contributing to a competitive inhibition of spring $\mathrm{Ni}$ uptake by roots of young transplanted trees. A similar reduction in Ni uptake may also occur in mature trees, but with the degree of inhibition usually being insufficient to trigger ME symptoms; although, there may be unrecognized disruption of one or more growth and developmental processes via disruption of $\mathrm{Ni}$ associated physiology.

These data indicate that $\mathrm{Ni}$ is absorbed by pecan foliage and is translocated from foliage to storage pools in dormant season tissues of shoots and/or buds. Although these amounts were not quantified, the amount translocated was enough to correct the deficiency of $\mathrm{Ni}$ 


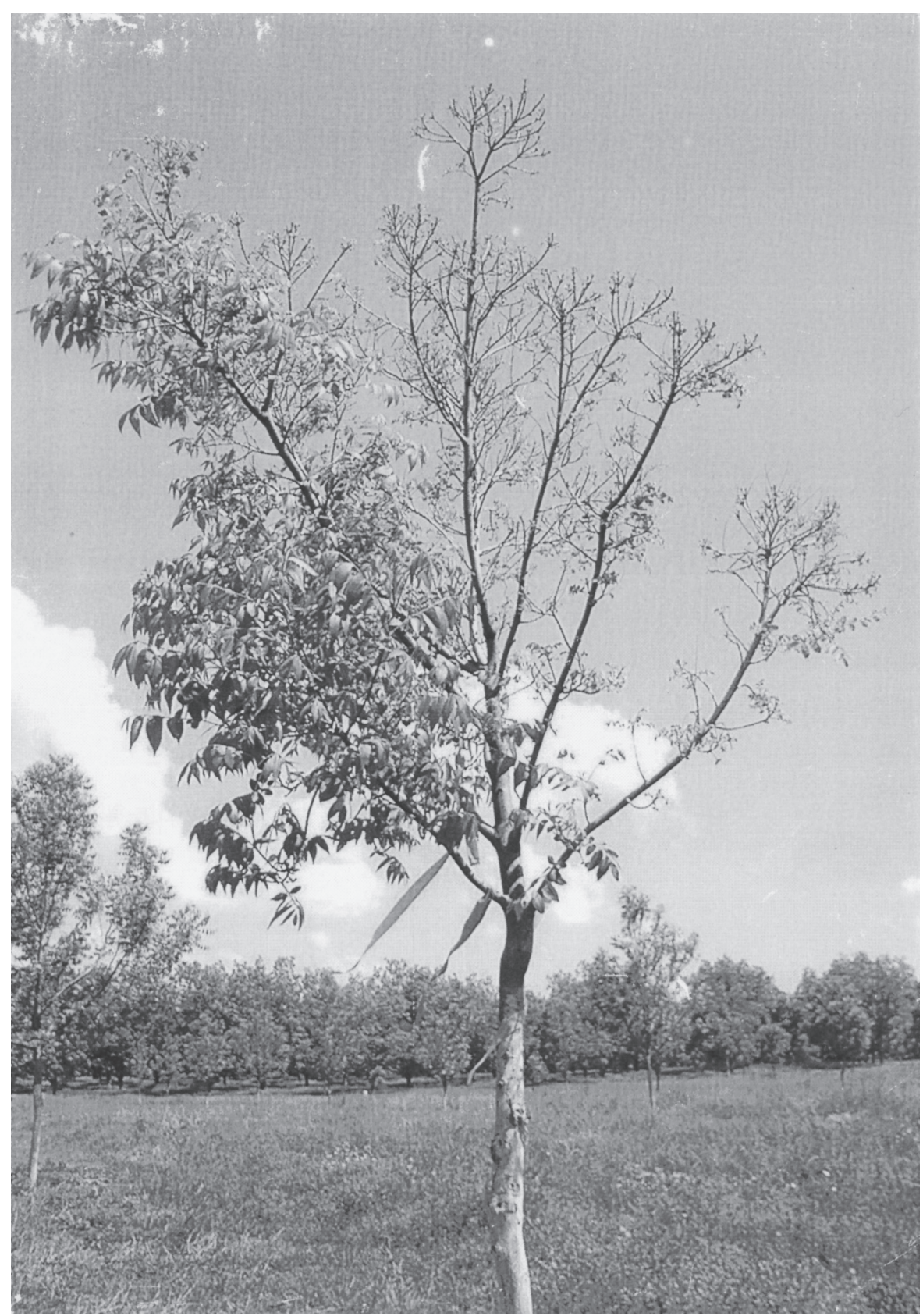

Fig. 2. Influence of spring foliar application of Ni on severity of mouse-ear symptoms of orchard trees. The branch on the left side of the tree was treated with Ni soon after budbreak whereas the right portion of the trees was not treated.

at budbreak and to enable normal growth processes. Foliar Ni content the following spring was $7 \mathrm{mg} \cdot \mathrm{kg}^{-1}$ in treatments receiving foliar Ni the previous October (Table 2). This compares to $\mathrm{Ni}$ at $0.5 \mathrm{mg} \cdot \mathrm{kg}^{-1}$ in foliage from non treated tissues of trees exhibiting severe ME. Adjacent trees not exhibiting ME had a foliar Ni concentration of $4 \mathrm{mg} \cdot \mathrm{kg}^{-1}$.

Spring application. Randomly selected limbs of all treatments initially exhibited severe ME immediately after budbreak, but before treatment with either $\mathrm{Cu}$ or $\mathrm{Ni}$. However, after $\mathrm{Ni}$ was applied, subsequent shoot, leaf, and leaflet growth (after about 10 to $15 \mathrm{~d}$ ) no longer exhibited ME; whereas subsequent growth after $\mathrm{Cu}$ application continued to exhibit severe ME symptoms (Table 1). Nontreated control shoots also exhibited severe ME. Sub- foliage in adjacent trees not exhibiting ME was $5 \mathrm{mg} \cdot \mathrm{kg}^{-1}$.

These data confirm the findings of the fall treatments that the ME replant disorder of young pecan trees is tightly linked to $\mathrm{Ni}$ and is Ni deficiency. The spotty necrosis of very young developing foliage indicates that the optimal concentration of $\mathrm{Ni}$ for spring applications is less than that used in the present study. The ability of foliar sprays of $\mathrm{Cu}$ to increase the severity of ME is taken as evidence that high $\mathrm{Cu}$ content may potentially disrupt $\mathrm{Ni}$ associated physiological processes.

\section{Greenhouse Studies}

Fall application. October foliar application of $\mathrm{Ni}$ and $\mathrm{Cu}$ to seedling trees in the greenhouse was such that Ni reduced and $\mathrm{Cu}$ increased $\mathrm{ME}$ severity (Fig. 3). The severity of ME decreased greatly with $\mathrm{Ni}$ treatments $\geq 1 \times$. No ME was evident in the $2 \times, 4 \times$, and $8 \times$ treatments, and very little in the $1 \times$ treatment. These data support those from field trees that fall applications of $\mathrm{Ni}$ to foliage will prevent the occurrence of $\mathrm{ME}$ the following spring. Conversely, fall application of $\mathrm{Cu}$ to seedling trees failed to correct ME and actually increased the severity of $\mathrm{ME}$ as the concentration of applied $\mathrm{Cu}$ increased (Fig. 3). Thus, ME does not appear to be associated with a $\mathrm{Cu}$ deficiency, as was previously suspected (Wood et al., 2004a, 2004b). This increased severity of $\mathrm{ME}$ in $\mathrm{Cu}$ treated seedlings, as a result of increasing amounts of foliar $\mathrm{Cu}$ applied the previous October, provides evidence that excessive $\mathrm{Cu}$ is interfering with $\mathrm{Ni}$ related physiological processes.

Spring application. Application of $\mathrm{Ni}$ two weeks after budbreak to ME seedlings previously treated with high amounts of $\mathrm{Cu}$, corrected ME symptoms in developing shoots, but had no curative effect on the morphology of older leaflets present before $\mathrm{Ni}$ application (Table 1). These data, a) support the above described field studies that post budbreak foliar application of $\mathrm{Ni}$ can correct $\mathrm{ME}$ of expanding foliage, $\mathrm{b}$ ) indicates that Ni corrects the increased severity of ME caused by foliar sprays of $\mathrm{Cu}$, and $\mathrm{c}$ ) that $\mathrm{Ni}$ and $\mathrm{Cu}$ are likely competing in certain physiological processes. Previous observations regarding the occurrence of severe ME at an orchard site also high in $\mathrm{Zn}$, plus increased ME severity when $\mathrm{Zn}$ is placed in the planting hole of new transplants (Wood et al., 2004b), is evidence that Zn may possibly compete with $\mathrm{Ni}$ in certain key physiological processes or is somehow reducing the physiological availability of $\mathrm{Ni}$.

Eskew et al. (1983 and 1984) identified $\mathrm{Ni}$ a likely essential micronutrient in higher plants. Subsequently, Brown et al. (1987a, 1987b) demonstrated nickel's essentiality as an essential plant nutrient element in several grain crops and suggested that it be recognized as an essential nutrient element for higher plants. It has therefore been noted as being of potential important in the cultivation of parsley [Petroselinum crispum (Mill.) Nyman ex A.W. Hill] (Atta-Aly, 1999), grains (Brown et al, 1990), legumes (Eskew, et al., 1983, 1984), and cucurbids (Watanabe and Shimada, 1990); po- 
Table 2. Ni content of foliage from orchard 'Desirable' trees exhibiting severe mouse-ear (ME) symptoms and trees in which ME was corrected with a foliar application of $\mathrm{Ni}$.

\begin{tabular}{lcc}
\hline Treatment & $\begin{array}{c}\text { Mouse-ear } \\
\text { severity } \\
(\text { class })^{\mathrm{y}}\end{array}$ & $\begin{array}{c}\text { Foliar Ni } \\
\text { concn }^{\mathrm{x}} \\
\left(\mathrm{mg} \cdot \mathrm{kg}^{-1}\right)\end{array}$ \\
\hline Normal tree control & $1.0 \mathrm{~b}^{\mathrm{w}}$ & $4.0 \mathrm{~b}^{\mathrm{w}}$ \\
Severe ME control & $7.4 \mathrm{a}$ & $0.5 \mathrm{c}$ \\
Severe ME + fall Ni & $1.0 \mathrm{~b}$ & $7.0 \mathrm{a}$ \\
Normal tree control & $1.0 \mathrm{~b}$ & $5.0 \mathrm{~b}$ \\
Severe ME control & $7.7 \mathrm{a}$ & $0.4 \mathrm{c}$ \\
Severe ME + spring Ni & $1.0 \mathrm{~b}$ & $26.0 \mathrm{a}$ \\
\hline
\end{tabular}

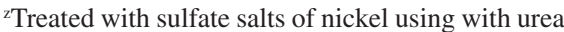
and nonionic surfactant. Treatments were applied to foliage in either mid-October (fall) or early April about $10 \mathrm{~d}$ postbudbreak (spring).

y Severity was based on the following scale; $1=$ no symptoms, 2 = between 1 and $25 \%$ of number of leaflets per shoot exhibiting blunting; $3=26 \%$ to $50 \%$ of number of leaflets per shoot exhibiting blunting; $4=>50 \%$ of number of leaflets per shoot exhibiting blunting; $5=$ cupping of blunted leaflets; $6=$ necrosis of leaflet tips; $7=$ dark green zone near leaflet tip; $8=$ stunted shoots; $9=$ multiple new shoots (i.e. witches broom) $10=$ dead shoot. Note that severity of the 'Severe ME + spring Ni' treatment is based on a rating of post-treatment foliage.

${ }^{x}$ Foliar Ni content is based on sampling of foliage in mid July, after Ni treatments the previous October and April. Content is based on dry weight.

${ }^{w}$ Means are statistically different according to Tukey-Kramer HSD test $(a=0.05)$ if followed by different letters.

tato (Solanum tuberosum) (Roach and Barklay, 1946), grape (Vitus vinifera L.) (Dobrolyubskii and Slavvo, 1957), and soybean [Glycine max (L.) Merrill] (Bertrand and de Wolf, 1973), but has received little or no attention as a needed supplement in tree crops or in fields, orchards, or vineyards. Because of the relative abundance of $\mathrm{Ni}$ in soils, and the apparent low Ni requirement of plants, it was thought that Ni would not be a practical problem in the field (Brown et al., 1987a). The above described studies on pecan indicate that the role of $\mathrm{Ni}$ in pecan tree nutrition has heretofore been overlooked. The chlorotic, or yellowish, coloration of leaflets and meristems of pecan trees with moderate to severe ME (Wood et al., 2004a) is consistent with $\mathrm{Ni}$ deficiency symptoms of several plant species (Welch, 1995). ME symptoms of growth depression and apparent disrupted protein synthesis and enzyme activity in pecan are consistent with $\mathrm{Ni}$ deficiency characteristics noted in other crops (Brown, 1990).

Wood et al. (2004b) noted that topical application of $\mathrm{Cu}, \mathrm{P}$, or $\mathrm{S}$ corrected ME symptoms by three years after application to a first generation orchard site. It was also noted that inclusion of either $\mathrm{Cu}$ or $\mathrm{P}$ in the backfill soil of transplanted trees reduced ME symptoms in proportion to the amount added, whereas $\mathrm{Zn}$ increased ME severity in proportion to the amount added. On the surface, these data provided evidence that $\mathrm{Cu}$ was the likely cause of ME. However, foliar applications of $\mathrm{Cu}$ over a wide concentration range over many different application dates did not correct the severe form of ME, but could occasionally reduce severity of a mild form of ME. Subsequent analyses of the $\mathrm{P}$ and $\mathrm{Cu}$ sources used in these studies

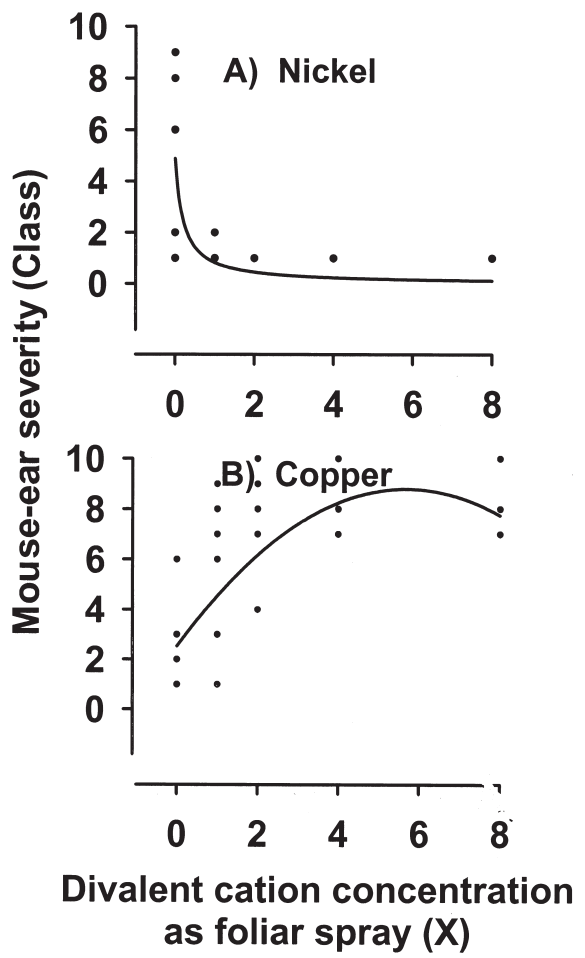

Fig. 3. Influence of October foliar application of $\mathrm{Cu}$ and $\mathrm{Ni}$ at different treatment concentrations on severity of mouse-ear the following spring. Treatments are such that for $\mathrm{Ni} \mathrm{X}=3.53 \mathrm{~g} \mathrm{NiSO}$ - $6 \mathrm{H}_{2} \mathrm{O} / \mathrm{L}(\mathrm{A})$, and for $\mathrm{Cu} \mathrm{X}=1.98 \mathrm{~g} \mathrm{CuSO}_{4} \cdot 5$ $\mathrm{H}_{2} \mathrm{O} / \mathrm{L}(\mathrm{B})$. For Ni, $y=1 /(x+0.205), R^{2}=0.45$, $P^{2}=0.0001$; for Cu: $y=2.95+2.06 x-0.183 x^{2}$, $R^{2}=0.54, P=0.0001$

revealed the presence of trace amounts of $\mathrm{Ni}(3$ to $\left.8 \mathrm{mg} \cdot \mathrm{kg}^{-1}\right)$. Thus, it appears that ME was not being corrected by $\mathrm{Cu}$ or $\mathrm{P}$, but rather by the $\mathrm{Ni}$ contaminate. Phosphorus fertilizers typically contain $\mathrm{Ni}$ as a trace contaminate (Martens and Westermann, 1991). Correction using S was likely because of a substantial soil acidification and subsequent increase in $\mathrm{Ni}$ availability on an orchard site low in both soil $\mathrm{Ni}$ and Zn. The influence of $\mathrm{Zn}$ on ME severity is evidence that high soil Zn indeed competitively inhibits the uptake of $\mathrm{Ni}$, thus resulting in $\mathrm{Ni}$ deficiency. The observation by Gammon and Sharp (1956) that $\mathrm{Mn}$ corrected Ni deficiency, but failed to do so in recent decades, is taken as evidence that the source of Mn used during that era likely contained trace amounts of $\mathrm{Ni}$ whereas improved manufacturing processes in recent years have substantially reduced the amount of $\mathrm{Ni}$ contamination in the Mn fertilizers.

The mid July to mid August Ni concentration of pecan foliage in Georgia is usually $<4 \mathrm{mg} \cdot \mathrm{kg}^{-1}$ and is often $<1 \mathrm{mg} \cdot \mathrm{kg}^{-1}$ in many orchards. This period is when foliage is sampled to assess tree nutritional status and fertilizer needs for the following growing season. Results from the present studies indicate that $\mathrm{Ni}$ nutritional needs of pecan merit reassessment. It is possible that pecan trees require foliar $\mathrm{Ni}$ concentrations higher than those typically reflected in leaf analysis reports. The role of $\mathrm{Ni}$ in pecan nutrition is not fully understood and was not included in the two most recent reviews of pecan macro and micro nutrient nutrition (Worley, 1994; Smith, 1991).

In the case of ME, it is possible that absolute or physiologically available $\mathrm{Ni}$ (and possibly $\mathrm{Cu}$ ) at budbreak, and a few weeks thereafter, is at a subcritical content due to any one of several factors. These factors could be adsorption to N-ligands, uptake inhibition by other divalent metals in the soil (e.g., $\mathrm{Zn}$ ) or due to dry soils. The absolute concentration of $\mathrm{Ni}$ in foliage may not be a reliable indication of $\mathrm{Ni}$ nutritional status, as the severity of ME in the above described greenhouse study was such that increasing the amount of $\mathrm{Cu}$ applied to foliage increased the ME severity. This implies that leaf $\mathrm{Cu}$ concentration can alter the physiologically available concentration of $\mathrm{Ni}$ or its ability to be used by certain enzymes. Additionally, Wood et al. (2004b) previously observed that foliar treatment of MEed trees with Fe enhanced the severity of ME (this was also observed with soil applications of $\mathrm{Fe}$ or $\mathrm{Cu}$ to potted pecan trees, unpublished observations). It therefore appears that the content of other trace metals in cells of pecan tissues can disrupt Ni nutrition.

The Ni nutrition of pecan, and likely that of other woody perennials, is likely affected by a wide variety of orchard management strategies known to influence Ni availability and uptake. Most notable among these are soil moisture and soil solution and leaf content of divalent cations, soil $\mathrm{pH}, \mathrm{P}$ or $\mathrm{Ca}$ or $\mathrm{Mg}$ fertilizers, and nitrogen fertilization practices (Wood et al., 2004b). Thus there is much that an orchardist can do to enhance the Ni nutrition of trees without application of Ni. These are discussed in detail by Wood et al. (2004b) within the context of $\mathrm{Cu}$, but the same actions and interactions for $\mathrm{Cu}$ are likely to also be generally true for $\mathrm{Ni}$.

\section{Conclusions}

The correction and prevention of $\mathrm{ME}$ symptoms in both field and greenhouse trees by foliar sprays of Ni indicates that the primary fundamental cause of ME is either closely related to, or is caused by, Ni deficiency. The occurrence and prevention of $\mathrm{ME}$ with $\mathrm{Ni}$, in first generation orchards, some of which had not supported crops for at least 100 years, is evidence that pecan trees growing on certain orchard sites are likely Ni deficient during a portion of the spring, yet are not so deficient as to exhibit ME symptoms. Thus, pecan Ni nutrition management needs to be reassessed.

In cases of severely mouse-eared trees growing in second generation orchards, it appears that ME is caused by a severe Ni deficiency induced by high soil Zn. This high soil $\mathrm{Zn}$ is a side-effect of $\geq 50$ years of $\mathrm{Zn}$ applications to pecan orchards for the correction of $\mathrm{Zn}$ deficiency. Thus, high soil Zn, and perhaps high plant Zn, appear to be directly or indirectly disrupting Ni related physiological processes of pecan. These results indicate that $\mathrm{Zn}$ management strategies for pecan merit reevaluation and imply that long-term applications of $\mathrm{Cu}$ or $\mathrm{Zn}$ containing fertilizers to woody plant crops may possibly induce Ni deficiency.

The influence of $\mathrm{Ni}$ on mouse-eared pecan 
trees provides field evidence to support the contentions of Eskew et al. $(1983,1984)$ and Brown et al. (1987a, 1987b) that Ni is an essential plant nutrient element. This is further supported in that Ni deficiency in pecan can be so severe as to cause young trees to die before fruiting, thus satisfying a key criteria for essentiality (Marschner, 2002). Because $\mathrm{Ni}$ uptake is directly inhibited by excessive $\mathrm{Zn}$ and $\mathrm{Cu}$ and indirectly inhibited by excessive nitrate- $\mathrm{N}, \mathrm{Ca}$ and $\mathrm{Mg}$; and because $\mathrm{Ni}$ is typically overlooked in plant nutrition management, it is postulated that $\mathrm{Ni}$ deficiencies are far more common in potted woody plants and orchard trees than commonly recognized. Such deficiencies are most likely to occur as a result of excessive fertilization with other metals or with N. Based on our experience with pecan, extreme cases of Ni deficiency are likely to be recognized by some combination of the following symptoms: blunted foliage, dwarfing, delayed budbreak, necrotic zones at the tip of leaves or leaflets, brittle shoots and branches, loss of apical dominance, rosetting, crinkled leaf or leaflet margins, slightly chlorotic foliage that later turns dark green, reduced growth, short internodes, and reduced flowering. The results of this study raises a multitude of questions regarding the economic, nutritional, and environmental impact of potentially unrecognized $\mathrm{Ni}$ deficiencies in a wide variety of horticultural crops and supports the role of $\mathrm{Ni}$ as an essential plant nutrient element.

\section{Literature Cited}

Atta-Aly, M.A. 1999. Effect of nickel addition on the yield and quality of parsley leaves. Scientia Hort. 82:9-24.

Bertrand, D. and A. de Wolf. 1973. Importance du nickel, comme oligo-element necessaire au mais. C.R. Acad. Sci. Ser. 267:2325-2326.

Brown, P.H. , R.M. Welch, and E.E. Cary. 1987a. Nickel: A micronutrient essential for higher plants. Plant Physiol. 85:801-803.

Brown, P.H. , R.M. Welch, E.E. Cary, and R.T. Checkai. 1987b. Beneficial effects of nickel on plant growth. J. Plant Nutr. 10:2125-2135.

Brown, P.H., R.M. Welch, and J.T. Madison. 1990. Effect of nickel deficiency on soluble anion, amino acid, and nitrogen levels in barley. Plant and Soil 125:19-27.

Demaree, J.B. 1926. Little leaf disease of pecans. Phytopathology 16:277-283.

Dobrolyubskii, O.K. and A.V. Slavvo. 1957. Use of trace element nickel for the nutrition of grapes. Dokl. Akad. Nauk. SSSR. 112:347-359.

Eskew, D.L., R.M. Welch, and E.E. Cary. 1983. Nickel and essential micronutrient for legumes and possibly all higher plants. Science 222:691-693.

Eskew, D.L., R.M. Welch, and W.A. Norvell. 1984. Nickel in higher plants: Further evidence for an essential role. Plant Physiol. 76:691-693.

Gammon, N. and R.H. Sharpe. 1956. Mouse-ear: A manganese deficiency of pecans. Proc. Amer. Soc. Hort. Sci. 68:195-200.

Kochian, L.V. 1991. Mechanisms of micronutrient uptake and translocation in plants, p. 229-296. In: R.J. Luxmoore (ed.). Micronutrients in agriculture. 2nd ed. Soil Sci. Soc. Amer., Inc., Madison, Wis.
Marschner, H. 2002. Mineral nutrition of higher plants. 2nd ed. Academic Press, New York.

Martens, D.C., and D.T. Westermann. 1991. Fertilizer applications for correcting micronutrient deficiencies. In: R.J. Luxmoore (ed.). Micronutrients in agriculture. 2nd ed. Soil Sci. Soc. Amer., Inc., Madison, Wis.

Marz, J. 1918. Diseases and insect pests of pecans. Fla. Agr. Expt. Sta. Bul. 147:135-163.

Roach, W.A. and C. Barclay. 1946. Nickel and multiple trace-element deficiencies in agricultural crops. Nature (London) 157:696.

SAS Institute, Inc. 2002. JMP statistics and graphics guide.: Reference. version 5. vol. 1. SAS Inst., Cary N.C.

Smith, M.W. 1991. Pecan nutrition, p. 152-158. In: B.W. Wood and J.A. Payne (eds.). Pecan husbandry: Challenges and opportunities. USDA ARS-96.

Watanabe, Y. and N. Shimada. 1990. Effect of nickel on the plant growth and urea assimilation in higher plants. Transactions $14^{\text {th }}$ Intl. Congr. Soil Sci., Kyota, Japan 4:146-151.

Welch, R. M. 1995. Micronutrient nutrition of plants. Critical Rev. Plant Sci. 14:49-82.

Wood, B.W., C.C. Reilly, and A.P. Nyczepir. 2004a. Mouse-ear of pecan: I. Symptomplogy and occurrence. HortScience 38:87-94.

Wood, B.W., C.C. Reilly, and A.P. Nyczepir. 2004b. Mouse-ear of pecan: II. Influence of nutrient applications. HortScience 38:95-100.

Worley, R.E. 1994. Pecan nutrition, p. 119-132. In: M.W. Smith, W.W. Reid, and B.W. Wood (eds.). Sustaining pecan productivity Into the 21 st century. 2nd Natl. Pecan Wkshp. Proc., Wagoner, Okla., 23-26 July 1994. USDA-ARS 1995-3. 